\title{
Comparative Advantage and Competitive Advantage: An Economics Perspective and a Synthesis
}

\author{
By Satya Dev Gupta*
}

\begin{abstract}
There is a considerable amount of controversy about the model(s) of comparative advantage and its applicability to international business, in particular as a guide to the success of nations and/or firms in international markets. This perception (or understanding) of inapplicability of the model(s) of comparative advantage has lead international business experts to develop new models, or what may be called frameworks, for analyzing the potential for success of firms and/or nations in international markets. These frameworks are popularly known as models of "competitive advantage". In the author's view, the model(s) of comparative advantage are too general to be dismissed altogether in this manner. While they may not be applicable to all circumstances in international business, they are valid models and can still offer meaningful predictions in a variety of circumstances. Furthermore, the models of comparative advantage used together with models of competitive advantage have the potential of offering a much richer analysis of international trade/business, normally not available with either the model(s) of comparative advantage or the model(s) of competitive advantage alone. The major aim of this paper is to establish a link between the principles of comparative and competitive advantage, and outline a synthesis of the two principles as a guiding force for gauging success of nations and/or firms in international trade/business.
\end{abstract}

\section{Introduction}

There is a considerable amount of controversy about the model of comparative advantage and its applicability to international business (Porter, 1985 and 1990; Hunt and Morgan, 1995 and 1996). Models/frameworks, popularly known as "competitive advantage", either interpret comparative advantage inaccurately or regard it as a useless edifice. Porter stated, "This doctrine, whose origins date back to Adam Smith and David Ricardo and that is embedded in classical economics, is at best incomplete and at worst incorrect." Porter (1990a, p.78)

*Professor of Economics, St. Thomas University, Canada.

https://doi.org/10.30958/ajbe.1-1-1

doi=10.30958/ajbe.1-1-1 
In the author's view, model(s) of comparative advantage used together with model(s) of competitive advantage have the potential of offering a much richer analysis of international trade/business, normally not available with either the model(s) of comparative advantage or the model(s) of competitive advantage alone.

The major aim of this paper is to establish a link between the principles of comparative and competitive advantage, and outline a synthesis of the two principles as a guiding force for gauging success of nations and/or firms in international trade/business. In the next two sections of the paper, we review the theories of comparative advantage and competitive advantage. In the penultimate section, we outline a synthesis of the models. The last section concludes the paper with some suggestions for further research in this area.

\section{Absolute and Comparative Advantage}

The literature on international trade and policy contains a number of reasons why a country may have an advantage in exporting a commodity to another country. For convenience, most of these reasons may be classified into (1) technological superiority, (2) resource endowments, (3) demand patterns, and (4) commercial policies.

\section{Technological Superiority}

Adam Smith's principle of "absolute advantage" and David Ricardo's principle of "comparative advantage", in general, are based on the technological superiority of one country over another country in producing a commodity. Absolute advantage refers to a country having higher (absolute) productivity or lower cost in producing a commodity compared to another country. However, absolute advantage in the production of a commodity is neither necessary nor sufficient for mutually beneficial trade. For example, a country may be experiencing absolute disadvantage in the production of all commodities compared to another country, yet the country may derive benefits by engaging in international trade with other countries, due to relative (comparative) advantage in the production of some commodities vis-à-vis other countries. Likewise, absolute advantage in the production of a commodity is not sufficient, since the country may not have relative (comparative) advantage in the production of that commodity. David Ricardo's principle of comparative advantage does not require a higher absolute productivity but only a higher relative productivity (a weaker assumption) in producing a commodity. Pretrade relative productivities/costs determine the pre-trade relative prices. Pretrade relative prices in each country determine the range of possible terms of trade for the trading partners. Actual terms of trade within this range, in general, depend on demand patterns, which, in turn determines the gains from trade for each trading partner. 
The Ricardian model assumes constant productivity, as there is only one factor of production (labour), and therefore constant (opportunity) costs that leads to complete specialization. However, increasing opportunity costs that often arise in multi-factor situations (law of diminishing returns) due to limited quantity of some factors specific to an industry can easily be accommodated to allow for incomplete specialization. Thus, in the Ricardian model, technological differences in two countries are the major source of movement of commodities across national boundaries.

While the principle of comparative advantage as expounded by David Ricardo was couched in terms of technological superiority, the principle, when phrased in terms of comparing opportunity cost or relative prices of goods and services between countries is sufficiently general to encompass a variety of circumstances. Furthermore, although Ricardo's explanation of comparative advantage was in static terms, comparative advantage is a dynamic concept. A country's comparative advantage in a product can change over time due to changes in any of the determinants of comparative advantage including resource endowments, technology, demand patterns, specialization, business practices, and government policies.

\section{Resource Endowments}

Availability of resources in a country provides another source of comparative advantage for countries that do not necessarily possess a superior technology. Under certain restrictive assumptions, comparative advantage can be obtained due to differences in relative factor endowments. As propounded by Heckscher (1919) and Ohlin (1933), a country has a comparative advantage in the production of that commodity which uses the relatively abundant resource in that country more intensively. For example, newsprint uses natural resources (forest products) more intensively compared to textiles. Textiles use labour (L) more intensively compared to newsprint. Canada is relatively abundant in natural resources $(\mathrm{R})$ compared to India. (R/L) Canada > (R/L) India. This implies $\mathrm{R}$ will be relatively cheaper in Canada as compared to India. Thus, Canada has a comparative advantage in newsprint and will therefore specialize and export newsprint to India. Likewise, India has a comparative advantage in textiles and will therefore specialize and export textiles to Canada.

\section{Human Skills}

Human skills can also be considered a resource. Countries with relatively abundant human skills will have a comparative advantage in products that use human skills more intensively. Certain products such as electronics require a highly skilled labour force (such as engineers, programmers, designers, and other professional personnel). Such products may gain comparative advantage in countries (such as Taiwan, Singapore, Hong Kong) that are relatively better endowed with such skilled labour. (Keesing, 1966). Government policies aimed at better education and training can create such an endowment. 


\section{Economies of Scale}

Economies of scale can provide comparative advantage by lowering production costs. External economies that operate by shifting the average cost of firms downward can in fact occur due to an industrial policy or a proactive role of the government in providing better infrastructure and/or a better educated or trained labour force. Such economies of scale are consistent with Ricardian and Factor Proportions models. Economies of scale (internal) achieved through the existence of a large home market and/or some policyinduced accessibility to a larger market outside the nation (say due to a customs union) also imply lower production costs. This may boost or create a comparative advantage for the industry experiencing such economies of scale. This later thesis is more consistent with market imperfections.

\section{Technological Gap (Benefits of an Early Start) and Product Cycle}

Industrially advanced nations in general had an early start in most manufactured products and services, which allowed them to enjoy large national and international markets. Industrially advanced nations were thus able to export new products until such time that the products were produced by other low factor cost countries. Vernon's (1961) Product Cycle hypothesis emphasizes the importance of the nature and size of home demand for new products in highly industrialized countries. Since, initially, the new product involves experimentation of the features of the product as well as the production process, the countries that have sufficient home demand for such products produce and export them. As the specific nature of demand becomes more universal and the technology more easily available to others, the nation loses comparative advantage in that product. Meanwhile, the firms are likely to have developed another product that enables the nation to gain comparative advantage in that product.

\section{Demand Patterns: Demand Considerations}

The role of demand and the size of the home market for products are already evident in (1) establishing the equilibrium terms of trade and therefore the division of gains from trade; (2) economies of scale; and (3) product cycle hypothesis. In addition, Linder (1961) emphasized the role of demand in the home market as a stepping stone towards success in international markets. According to Linder, manufacturers initiate the production of a new product to satisfy the local market. In this step, they learn the necessary skills for making the product by more efficient techniques, which in turn, give these nations comparative advantage in the product vis-à-vis other countries. Linder's thesis postulates exporting the product to countries with similar tastes/demand patterns. The theory, coupled with market imperfections and product differentiation can explain a large portion of intra-industry trade among the industrialized nations. 


\section{National and International Policies}

National policies towards infrastructure, export promotion, education and training, and R\&D policy related to export industries can go a long way in creating and sustaining comparative advantage. Industrial policies such as production subsidies, tax preferences, restricted tendering of Government contracts, anti-trust policy, and a number of other means are often used to provide an advantage to domestic industries. Likewise, the commercial policies aimed at restricting imports through tariffs, quotas, voluntary export restraints, import licensing, local content rules, restriction on outsourcing, escape clauses, etc. have been used to the advantage of domestic import competing industries. Policy driven benefits realized by the industries through internal and/or external economies, in the long run, may become a source of comparative advantage to these industries. The 1965 Auto-Pact between Canada and the USA is a good example of targeting individual industries to influence production and trade through national policies.

The trade creation and trade diversion effects of customs unions/free trade areas are well known in the literature. Eicher, Hehn and Papageorgiou (2008) provide an extensive review of the literature on the subject. Based on their statistical analysis of twelve preferential trading arrangements (PTAs) such as the Asian Pacific Economic Cooperation (APEC), European Union (EU), North American Free Trade Agreement (NAFTA), Southern Cone Common Market (MERCOSUR), they report clear evidence of trade creation and trade diversion in a number of PTAs. Further, the policies pursued by international organizations such as the IMF and the WTO can also become a source of comparative advantage/disadvantage to some industries in countries affected by such policies. For example, IMF programs and financial assistance to countries have often been conditional on carrying out trade enhancing reforms by those countries (IMF, 2005). The WTO celebrating its $50^{\text {th }}$ anniversary of its multilateral trading system in 1998 claimed, "Since the General Agreement on Tariffs and Trade began operating from Geneva in 1948, world merchandise trade has increased 16 fold and is forecasted to increase 22-fold by 1998 . World trade now grows roughly three times faster than merchandise output. Global exports of goods and services are currently worth more than \$6 trillion." (WTO, 1998).

\section{Dynamic Gains /Comparative Advantage}

International trade, through a better allocation of resources, increases incomes, savings, and investment. This in turn enables a country to realize a higher growth potential even in fully employed economies. In addition, for developing countries, trade can enable them to transform consumption goods and raw materials into capital goods as well as gain technological knowhow from technologically advanced countries. Trade can also provide demand stimulus to the lagging (excess capacity of some factors of production) economies. Furthermore, specialization through trade benefits not only the export industry, but all other industries (through increased demand for their products) related to the export industries. Lastly, by increasing the size of 
national market and thereby the size of production facilities, domestic firms can reap both external and internal economies of scale. International trade also places competitive pressures on domestic firms, which stimulates research and development.

All these considerations yielding comparative advantage to the nation may be seen as a framework of a number of forces that can be portrayed in the form of a diamond shown in Figure 1. Obviously, the firms specializing within the industries that have comparative advantage are on a much stronger footing to derive competitive advantage in producing standardized or differentiated products within that industry. In this framework, technology, resources, demand and the trade-enhancing policies are depicted as four forces influencing the comparative advantage of a nation in a commodity/service visà-vis other countries. Dynamic elements influencing comparative advantage are also included in these forces.

Figure 1. A Framework for Comparative Advantage

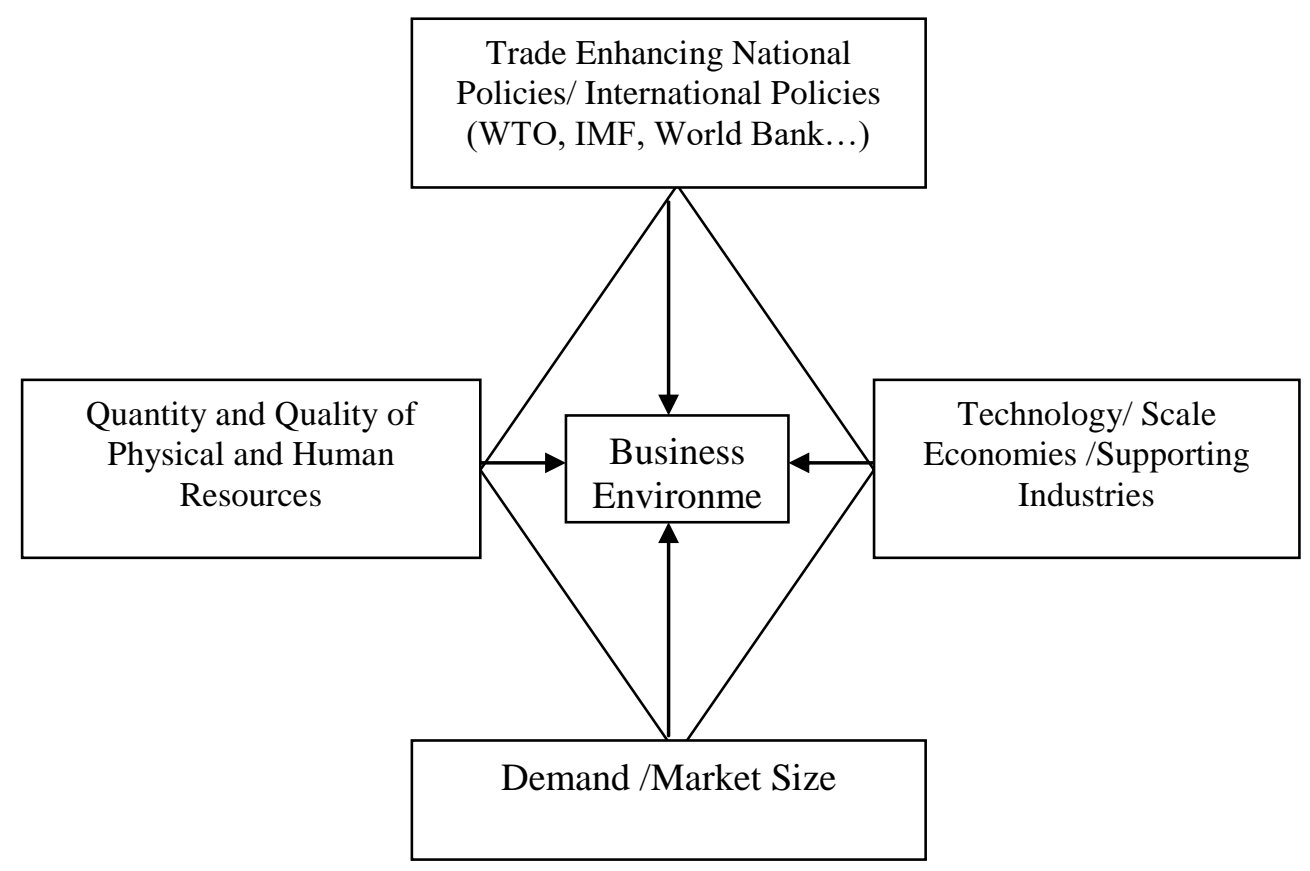

\section{Competitive Advantage}

What exactly is competitive advantage, and how does it differ from comparative advantage? In a recent article Peter Neary (2003), attempting to advance the theory of comparative advantage in the presence of market imperfections (oligopoly in a general equilibrium framework) stated the following for a general understanding of competitive advantage in the economics profession: 
Comparative advantage is widely believed by economists to be a key determinant of international production and trade patterns. But noneconomists typically think otherwise. In business schools and business circles much greater emphasis is placed on the role of competitive advantage as a predictor of the economic fortunes not just of firms, but nation as a whole.

What exactly is competitive advantage? And how, if at all, does it relate to and interact with comparative advantage? One possible answer is that it is something to do with more competitive markets: lower barriers to entry or simply a large number of firms may give an industry an advantage in competing with foreign rivals. A different answer is that competitive advantage is just a synonym for absolute advantage: some natural or policy-induced superiority (such as lower taxes or greater labour-market flexibility) which reduces costs for all home sectors...A different approach to understanding competitive advantage, exemplified by Porter (1990), is to use a case-study evidence to identify the factors, which encourage a nation's firms to achieve high world market shares in their industries. For the most part, economists have either ignored Porter's approach or dismissed it as merely a restatement of comparative advantage (see Warr, 1994). (Neary 2003, p.457-8)

Following Porter's development of the concept of competitive advantage, the profession has witnessed a voluminous literature on the subject. Nicole Hoffman (2000) contains an excellent survey of these developments. However, there is no unanimity on the meaning and/or the sources of competitive advantage.

Porter (1985) emphasised competitiveness at the level of a firm in terms of competitive strategies such as low cost and/or product differentiation. However, his description of competitiveness did not entail a formal conceptual definition. As noted by Cho (1998, p.11), "Despite all discussions on competitiveness however, no clear definition or model has yet been developed. There is even ongoing debate about the "entity" of competitiveness." Hoffman (2000) developed a definition of sustainable competitive advantage (SCA) based on a similar definition by Barney (1991) and the dictionary meanings of each term as "An SCA is a prolonged benefit of implementing some unique value-creating strategy not simultaneously implemented by any current or potential competitors along with the inability to duplicate the benefits of this strategy." (Hoffman 2000, p.4). Obviously, this definition emphasises competitive advantage of a firm based on firm-specific factors and thus ignores macro aspects of comparative advantage.

A number of writers on competitive advantage have focused on its determinants/sources such as important attributes of the firm: rareness, value, inability to be imitated, and inability to be substituted (Barney, 1991); important potential resources classified as financial, physical, legal, human, organizational, informational, and rational (Hunt and Morgan, 1996); ability in 
developing superior core competencies in combining their skills and resources (Prahalad and Hamel, 1990); a set of dynamic capabilities - capabilities of possessing and allocating and upgrading distinctive resources (Luo 2000). A number of studies have also analysed the role of individual factors such as intellectual property rights, trade secrets, data bases, the culture of organization, etc. (Hall, 1993), ethics capability (Buller and McEvoy, 1999), corporate reputation (Ljubojevic, 2003), diversity in workplace (Lattimer, 2003) and corporate philanthropy (Porter and Kramer, 2002). The central focus of these contributions is still on firm-specific factors of competitive advantage.

Porter (1990) developed a framework of competitive advantage "A Diamond of National Advantage" based on detailed case studies of firms in 100 industries in 10 industrially advanced nations (USA, Japan, Germany, UK, Switzerland, Italy, Sweden, Denmark, Sweden, Korea and Singapore) that constituted $50 \%$ of world exports in 1985 . The central thesis behind Porter's analysis is that a nation's success/prosperity through trade is not "inherited". It does not depend on the nation's endowment of resources or the exchange rates. A nation's prosperity is "created" by the nation's firms that are successful in the world markets. "A nation's competitiveness depends on the capacity of its industry to innovate and upgrade. Companies gain advantage against the world's best competitors because of pressure and challenge. They benefit from having strong domestic rivals, aggressive home-based suppliers, and demanding local customers." (Porter, 1990a, p.73)

For a nation's industry to have competitive advantage, it must display its success in terms of substantial and sustained exports and/or foreign investment. Innovation in every sphere of a firm's activities plays the central role in awarding competitive advantage to a firm and therefore the industry. Why some firms are more capable of successful innovations depends on four attributes of a nation: factor conditions, demand conditions, related and supporting industries, and firm strategy, structure, and rivalry.

Factor conditions do not refer to the conventional pool of resources, such as land, labour, capital, raw materials, but rather those "created" and continually upgraded such as highly specialised skilled labour, and world-class scientific institutions most suited to the industry's needs. The Demand conditions refer to, not the size, but the character of home market demand--the sophisticated and demanding buyers who can signal the future pattern of demand and can pressure the companies to innovate faster compared to competitors elsewhere. Related and supporting industries that are internationally competitive, and in particular, actively engaged in innovation and upgrading are more promising in creating competitive advantage rather than the mere existence of raw material and/or component producing industries. Firm strategies, structure and rivalry refer to managerial, organizational as well as the existence of competitive forces/challenges from other firms within the industry. While the managerial/organizational modes must be compatible with other sources of competitive advantage, existence of domestic rivalry is considered sine-qua-non as well as an integrating force in the "diamond". It forces companies to a continual challenge for innovation and 
upgrading in all forces in the "diamond" and makes the working of the diamond as a system in gaining and sustaining competitive advantage. Porter presents these forces in the form of a "diamond" depicted in Figure 2 (adapted from Porter 1990a, p.77).

Figure 2. Determinants of National Competitive Advantage

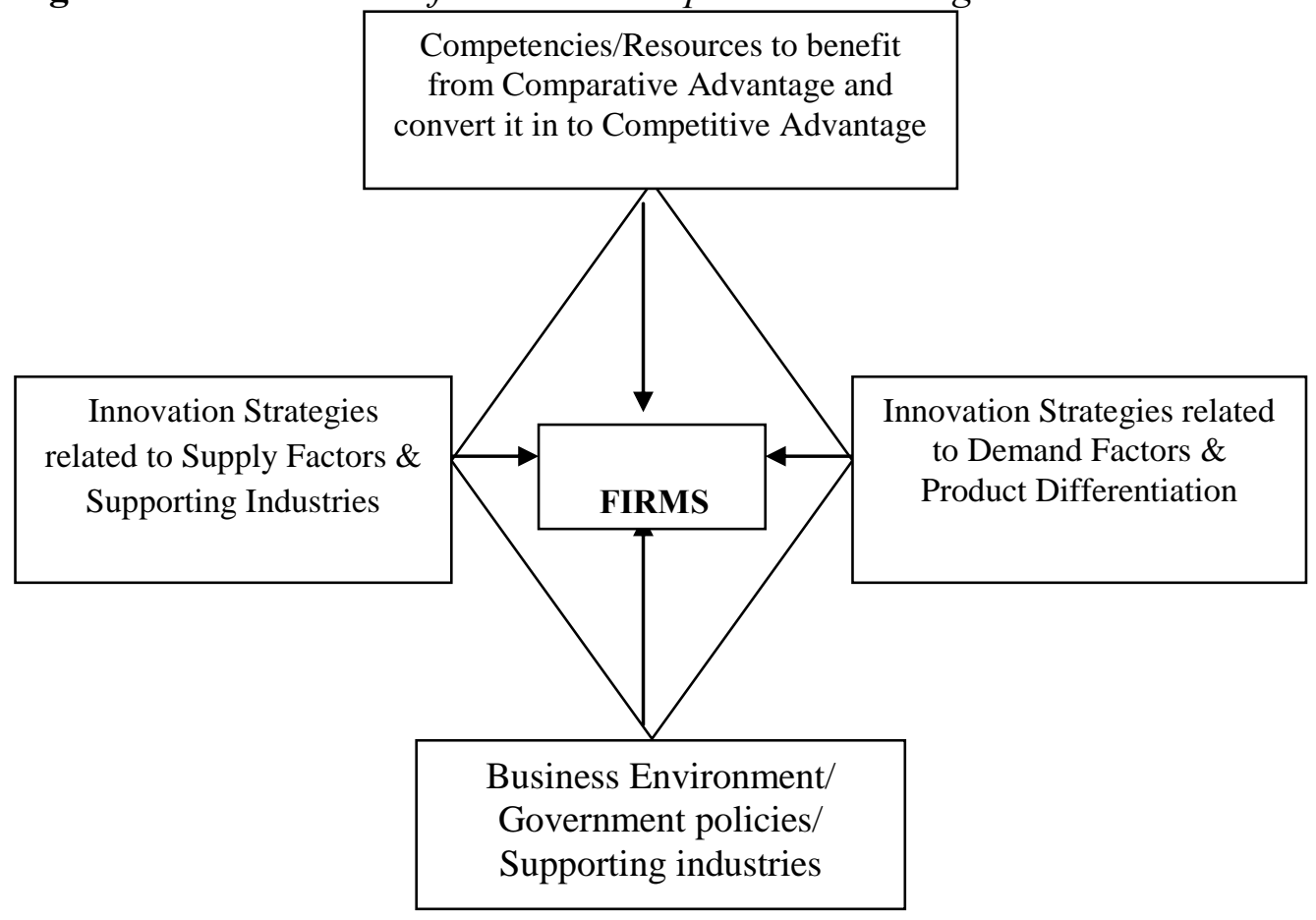

As is obvious from the description and operation of the forces in the "diamond", the competitive advantage of an industry is driven by firm-specific factors, the competitive environment, and the push towards innovation and upgrading. The basic differences in the framework of competitive advantage visà-vis factors influencing comparative advantage are (1) an emphasis on "created" factors of production and innovation by the firms in competitive advantage versus the "inherited" factors of production and technology with dynamic elements at the national level; (2) an emphasis on demand side, particularly firm's success in creating a differentiated product with some unique characteristics within the same industry in competitive advantage versus market size for products of each industry in comparative advantage; (3) an emphasis on gaining monopoly or niche by successful firms in markets for their products in competitive advantage versus emphasis on traditional models of competition in comparative advantage; and (4) an emphasis on explaining intra-industry trade in advanced industrialised economies in competitive advantage versus inter-industry trade in comparative advantage. Thus, in general, the competitive advantage framework relies on the "bottom-up" approach of a nation as compared to the "top-down" approach in the models of comparative advantage. What we need is a synthesis of the two frameworks for a better explanation of international trade in all good and services. 


\section{Linking Comparative Advantage to Competitive Advantage}

Figure 3. Linking Comparative Advantage to Competitive Advantage: A Schematic Feedback Framework

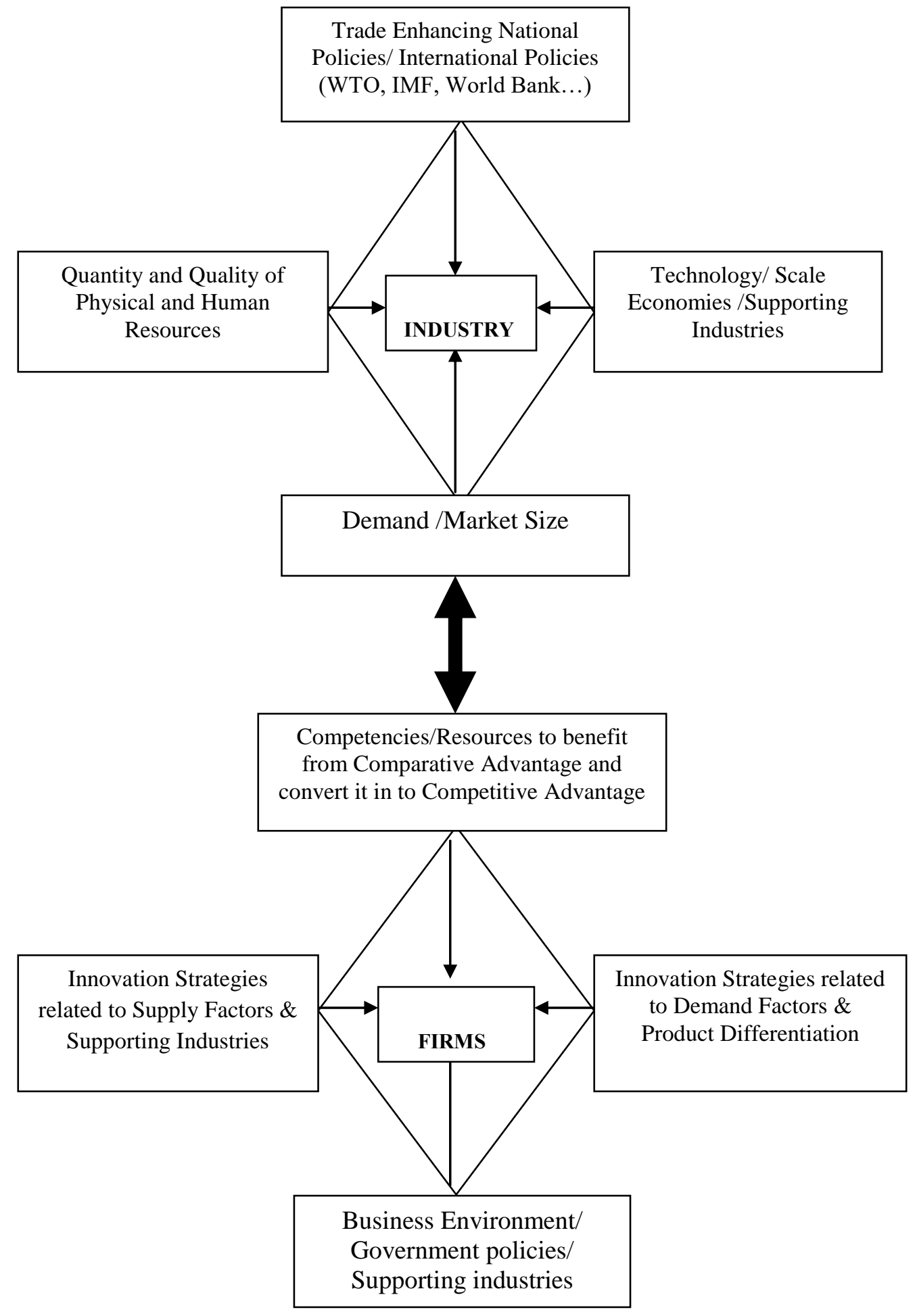


As is evident from the two approaches, competitive advantage relies heavily on the firm-specific factors such as "created" factors, "created" demand for the product, and internal economies achieved through innovation. Comparative advantage, on the other hand emphasises nationally "endowed" factors, differences in international technology/productivity, external economies, and international policies. The forces underlying both competitive advantage and comparative advantage are important in deriving a nation's advantage in trade. In fact, the forces under competitive and comparative advantage can be seen as reinforcing each other in explaining a nation's advantage in international trade.

A pragmatic approach would therefore entail linking the forces under both competitive and comparative advantage, as shown in Figure 3. For trade among the developed countries, particularly the intra-industry trade, firm level forces (competitive advantage diamond) are stronger compared to the country level forces. For trade between the developed and the developing countries (or the resource-rich countries), particularly the inter-industry trade, country level forces (comparative advantage diamond) are stronger compared to the firm level forces. Further, the same country may gain advantage in intra-industry trade with some countries as well as inter-industry trade with some other countries.

Strength of the feedback from the firm level forces to the country level forces depends on the strength of R\&D and innovation strategies carried out by firms in supply factors and supporting industries, demand factors and product differentiation, and national competition policy. The strength of the feedback from the country level forces to the firm level forces depends on the differences in factor endowments and technology between countries, the degree of national involvement in infrastructure, skill training, and the macro policies suitable for international trade and investment. In general, in a static world, a country and the firms in that country will enjoy competitive advantage if firms in that country specialize in the products in which a country has a comparative advantage. In a dynamic world, firms will benefit from enhancing comparative advantage of their nations through forces of competitive advantage, where created factors and cutting-edge technology and innovation assume greater importance. The competitiveness of nations measured by organizations such as the World Economic Forum (2000) and the International Institute of Management Development (2000), though not suitable for our purpose, uses both micro and macro variables.

It is possible to illustrate the principles of comparative and competitive advantage at work by Canada's international trade. Canada enjoys a relative abundance (relative to labour and semi-skilled labour) of capital and a number of natural resources such as minerals, forest and agricultural land as compared to a number of developing countries such as Brazil, China, India and Indonesia. Canada's exports to these countries are predominated by transport equipment, heavy machinery, newsprint, wood pulp, wheat, minerals, mineral and chemical fertilizers; whereas commodities such as clothing, footwear, toys, light electronic items predominate Canada's imports from the developing 
countries. Diamonds from India and natural rubber and rubber products from Indonesia are also important in Canadian imports from these countries. Natural resource intensive goods also predominate in Canada's exports to countries such UK and Japan. Canada's trade, both imports and exports, with USA, its largest trading partner, is still predominated by transport vehicles, a result of the Auto-Pact since 1965 - a good example of the influence of national policies on international trade.

However, the competitive advantage developed by the Canadian auto industry is also responsible for Canadian exports of automotive parts and vehicles to nearly 50 other countries in the world. Canada is also engaged in intra-industry trade with several countries (with similar endowments of labour, capital and technology) in a number of industries such as aircraft and aircraft parts, electronic computing and peripheral equipment, telecommunications equipment, medicaments, etc. This trade is more easily explained by the "bottom-up" approach of the competitive advantage framework.

\section{Concluding Remarks}

The model(s) of comparative advantage are too general to be dismissed altogether in the search for the competitive advantage of nations. While they may not be applicable to all circumstances in international business, they are valid models and can still offer meaningful predictions in a variety of circumstances. Furthermore, the models of comparative advantage used together with models of competitive advantage have the potential of offering a much richer analysis of international trade/business, normally not available with either the model(s) of comparative advantage or the model(s) of competitive advantage alone.

In this paper, the major forces influencing both comparative and competitive advantage in the form of two separate "diamonds"/frameworks were identified. Both diamonds were then linked to offer a better explanation of the competitive advantage of nations. Forces in the comparative advantage diamond are seen to influence forces in the competitive advantage diamond and vice versa. In our view, pursuing the forces related to competitive advantage in those goods and services in which a nation already has some comparative advantage offers a better promise for success in gaining competitive advantage for the nation. In this "double diamond" framework, it is also possible for forces of competitive advantage to further strengthen the operation of the forces of comparative advantage or even help create comparative advantage in goods and services, hitherto not available based solely on classical theories of comparative advantage. In general, this paper shows how the models of competitive advantage and comparative advantage complement each other in determining and sustaining a nation's advantage in international trade and business. However, more research needs to be done to crystalize these ideas in a more refined framework, and to provide a solid empirical foundation for these ideas. 


\section{Acknowledgments}

I wish to thank the participants at the conference of Canadian Economics Association (May, 2009) and Dr. Santosh Kabadi for their valuable comments.

\section{References}

Barney, J.B. 1991. Firm Resources and Sustained Competitive Advantage, Journal of Management, vol.17 (1).

Buller, Paul F. and McEvoy, Glenn M. 1999. Creating and Sustaining Ethical Capability in the Multi-National Corporation, Journal of World Business, vol. 34 (4)

Cho D.S. 1998. From National Competitiveness to Bloc and Global Competitiveness. Competitiveness Review, vol. 8 (1).

Eicher, Theo, Hehn,Christian, and Papageorgiou, Chris 2008. Trade Creation and Diversion Revisited: Accounting for Model Uncertainty and Natural Trading Partner Effects, IMF Working Paper (WP/08/66), International Monetary Fund.

Hall, Richard 1993. A Framework Linking Intangible Resources and Capabilities to Sustainable Competitive Advantage, Strategic Management Journal, vol. 14 (8).

Heckscher, Eli. 1919. The Effects of Foreign Trade on the Distribution of Income, (originally published in 1919), In Readings in the Theory of International Trade, ed. Howard S. Ellis and Lloyd M. Metzler, Philadelphia: Blakiston, 1949.

Hoffman, Nicole P. 2000. An Examination of the "Sustainable Competitive Advantage" Concept: Past, Present, and Future, Academy of Marketing Science Review, vol. 2000 (4), available at http://www.amsreview.org/articles/hoffman 04-2000.pdf.

Hunt, Shelby D. and Morgan, Robert M. 1995. The Comparative Advantage Theory of Competition, Journal of Marketing, vol. 59 (April).

Hunt, Shelby D. and Morgan, Robert M. 1996. The Resource-Advantage Theory of Competition: Dynamics, Path Dependencies, and Evolutionary Dimensions, Journal of Marketing, vol. 60 (October).

IMF, 2005. Trade Conditionality Under Fund-Supported Programs, 1990-2004 (Background Paper to the Review of Fund Work on Trade), Prepared by the Policy Development and Review Department, International Monetary Fund, available at https://www.imf.org/external/np/pp/eng/2005/021405.pdf.

International Institute of Management Development. 2000. World Competitiveness Yearbook, Switzerland.

Keesing, D. 1966. Labour Skills and Comparative Advantage, American Economic Review, May.

Lattimer, Robert 2003. The New Age of Competitiveness, Competitiveness Review, vol. 13 (2).

Linder, S. 1961. An Essay on Trade and Transformation, New York: Wiley.

Ljubojevic, Cedomir. 2003. Corporate Competence-the Basis of Achieving Competitive Advantage of Services Business on the Global Market, Paper presented to Conference on Globalization and Entrepreneurship: fears, Challenges and Opportunities, Pula, Croatia, April 24-26.

Luo, Yadong. 2000. Dynamic Capabilities in International Expansion, Journal of World Business, vol. 35 (4). 
Neary, J. Peter. 2003. Competitive versus Comparative Advantage, World Economy, vol. 26 (4).

Ohlin, B. 1933. Interregional and International Trade, Cambridge, MA: Harvard University Press.

Porter, Michael E. 1985. Competitive Advantage: Creating and Sustaining Superior Performance. New York: The Free Press.

Porter, Michael E. 1990. The Competitive Advantage of Nations, New York: The Free Press.

Porter, Michael E. 1990a. The Competitive Advantage of Nations, Harvard Business Review, March-April.

Porter, Michael E. and Kramer, Mark R. 2002. The Competitive Advantage of Corporate Philanthropy, Harvard Business Review , December.

Prahalad, C. K. and Hamel, G. 1990. The core competence of the Corporation., Harvard Business Review, May-June.

Vernon, R. 1961. International Investment and Trade in the Product Cycle, Quarterly Journal of Economics, May.

Warr, P.G. 1994. Comparative and Competitive Advantage. Asian Pacific Economic Literature, vol 8, no 2, 3-14.

World Economic Forum. 2000. World Competitiveness Report, Switzerland.

WTO 1998. Press Brief, Fiftieth Anniversary of the Multilateral Trading System, available at http://www.wto.org/english/thewto_e/minist_e/min96_e/chrono.htm. 